\title{
MATRIMONIAL PROPERTY LAW: THE MOVEMENT TOWARDS EQUALITY - SEPARATION OR COMMUNITY?
}

\author{
Canadian (especially Albertan) and English Experience \\ OLIVE M. STONE*
}

\begin{abstract}
The influence of the common law on the development of matrimonial property law in Canada is discussed in this historical view of the subject. Separation of property and community property are explained, with illustrations from Commonwealth cases. In conclusion, the author compares the legislation which has been enacted in selected foreign jurisdictions with that which exists in Canada, and suggests a personal view of the main principles to be considered in any current legislation.
\end{abstract}

\section{THE COMMON LAW INCLUDING EQUITY AND STATUTE}

English law is based on what is still called The Common Law, as interpreted by the judges and amended by statute (also interpreted by the judges), over some 800 years. The usual approach of any common lawyer to a problem is to consider (1) the original common law; (2) the 'gloss' on the common law constituted by the rules of equity, which was administered from the 12th century until 1875 by the separate Court of Chancery; (3) the effect on the common law (including equity) of legislation passed by Parliament; and finally the effect of judicial decisions of the superior courts in interpreting this legislation, integrating it with the common law, applying the law to the facts of a particular case and laying down the general principles applicable to similar cases in the future.

The common law applies in England and Wales, it does not now and never has applied in Scotland, which has its own system of civil law derived from the Roman Law, much more akin to the laws found in Continental Europe than to the common law. ('British' law is an American invention, which has no existence in fact apart from Constitutional Law.) But when the English, Irish, Scots and Welsh took to the High Seas and from the 16th century set up settled colonies in lands previously only sparsely inhabited if at all, they were presumed to take with them not the law to which each colonist had in fact been subject within the British Islands, but the common law of England and Wales, including equity and statute. This applied amongst others to the colonists who settled in the original 13 colonies of what is now the United States of America, throughout Australia and New Zealand, and in the greater part of what is now Canada.

\section{(A) Canada and Alberta}

1. The date at which English law was "received" in the various provinces and territories of Canada and throughout Federal Canada as a whole is a somewhat technical matter not very relevant to matrimonial property law. For present purposes it is sufficient to say that:

(a) The Dominion of Canada was created by the British North America Act, 1867, from the four provinces of Upper Canada (now Ontario), Lower Canada (now Quebec), Nova Scotia and New Brunswick. All were at that time subject to English criminal law

- Ph.D., LL.B., B.Sc. (Econ), (London). Author of Family Law: Macmillan Press Ltd., 1977. 
and all but Quebec to English civil law. Quebec retained the French law of property and civil rights operative at the date of its conquest by the British in 1759 , as subsequently amended by local statute.

(b) When the Province of Manitoba was created and admitted to the Federation on July 15, 1870, it received English civil and criminal law as it was at that date, and when in 1905 the Provinces of Saskatchewan and Alberta were created and admitted to the Federation it was confirmed that the laws of England as at July 15,1870 , remained in force within them "so far as applicable" and insofar as they had not since been amended by competent legislative authority.

\section{English Matrimonial Property Law as at}

July 15, 1870, Received in Alberta

(a) At Common Law the wedding ceremony operated to deprive the woman of her independent right to contract, to sue or be sued or to make a will. It conveyed to her husband all her personal property (chattels), rights and obligations as at the date of the ceremony. Her leasehold land was not in theory conveyed to him, but since he was entitled to sell it and appropriate the proceeds the distinction was without substance. In respect of freehold land to which she had been entitled in her own right, the husband acquired the rights to manage and control and draw the income from it during the marriage (the lifetime of both). As soon as the wife bore a living child capable of inheriting the land from her, the husband's right was by the "curtesy" extended to the duration of his own life should he survive her. His theoretical inability to sell the land and appropriate the price was circumvented by a fictitious lawsuit called a Fine. On the other hand, since he had by marriage acquired all her property, and the law had entirely merged her legal personality in his, the law fixed on him a liability which it was never able to enforce, that he must maintain her for her life provided she did not commit adultery. The only method of enforcement at common law was for the wife to persuade others to supply goods and services to her and collect the value from the husband. No one who knew the law would supply a married woman without her husband's prior consent. Should she survive her husband, the widow had the right of dower, viz., to receive from the heir the income of one-third of the freehold lands to which her husband had been entitled during the marriage, so that, as Lord Simon of Glaisdale has said, the widow at common law 'looked like a pensioner of the heir rather than a partner of the ancestor'.

But for one characteristic the common law system of matrimonial property would have resembled an unusual form of the system of total community of property widespread in medieval Europe and still existing, for example, in Belgium, where it is commonly said that "the community is the husband and the husband is the community". One additional deformity prevented any such resemblance: by the middle of the sixteenth century the system of legitim, or reasonable part for wife and children of a deceased's personal property was in decline. Thereafter the theory of irresponsibility, misnamed "freedom" of testation prevailed, under which a man who had taken all his wife's personal property and drawn during life the income from her land was entitled at his death to dispose of all "his" (meaning her) property as he chose, leaving widow and children destitute. 
(b) Equity. For several centuries those entitled to capital, whether in the form of land or moveable property, had not allowed such a barbarous system to govern their affairs. From the sixteenth century at least, property to which a woman was entitled would be settled before or during her marriage "to her separate use". This meant that the property vested in trustees, who were bound to manage it in the beneficiary's interests and pay the income from it to her. If there was a clear settlement but no trustee was appointed, equity would regard the husband as a trustee for the wife. The details would depend on the terms of the settlement. From the sixteenth century equity would only assist a husband to reduce his wife's property into his possession provided he made a settlement on her which the Court of Chancery considered proper, and in the middle of the eighteenth century the Restraint on Anticipation was invented, which prevented a married woman from touching the capital and perhaps passing it over to her husband as the result of 'kicks and kisses'. She could draw only the income from the settlement as it became payable.

(c) In 1857 by statute questions of marriage and divorce and of succession to personal property at death were for the first time in a thousand years taken out of the hands of the church and entrusted to the secular courts. For the first time a court was specifically empowered to terminate a marriage and release the parties from its bonds by a divorce $a$ vinculo matrimonii. Some provision had therefore to be made for the maintenance of divorced women. By s. 24 of the Act of 1857, the court was empowered to order a former husband on divorce to pay alimony to or on behalf of his former wife. The Act also improved the position of the women still married. By ss. 25 and 26 the woman judicially separated from her husband, under the then new equivalent of the old divorce $a$ mensa et thoro became a feme sole, that is she was considered an unmarried woman insofar as she recovered during the separation her ability to make contracts, sue and be sued for delicts, and receive, hold and dispose of property of any description, or make a will. If she died intestate, any property she owned at death devolved as if her husband were dead. Even more thoroughgoing was 8. 21 of the 1857 Act, which provided that the married woman who was deserted by her husband could apply for a Protection Order. This protected any money or property she might acquire, including her earnings, against any claims by her husband or his creditors.

These then, are the main outlines of the English law of property received by the Province of Alberta and all other Provinces of Canada except the present Province of Quebec, which retained French civil law as at 1759 , as later locally amended. It is true that the first English Married Women's Property Act was passed and became operative in 1870, but on the 9th August of that year, less than a month after the 'reception' of the unreformed English law by the Prairie Provinces.

\section{The Division of Legislative Powers Between the Canadian \\ Federation and Its Provinces and Territories}

The division of powers as between Federal Canada and the various Provinces and Territories is still as laid down by the British North America Act 1867 (very slightly modified by later statutes) and especially in sections 91 and 92 of that Act, which allocate legislative powers. As far as matrimonial property is concerned, the relevant provisions are: 
(a) The Federal Parliament has exclusive jurisdiction to legislate for Marriage and Divorce: B.N.A. Act 1867, s. 91(26).

(b) The Provincial Legislatures have exclusive jurisdiction to legislate for.

(i) The solemnization of marriage in the province B.N.A. Act 1867, s. 92(12)

(ii) Property and civil rights in the province: s. 92(13).

Any division of powers between different authorities produces complications and borderline cases. If powers within the various areas of family law were being divided today between federal and provincial authorities, it is unlikely that the division would bear any close resemblance to that appearing in the Act of 1867, but until it is amended the Act of 1867 applies.

Until 1968 the federal legislative power in respect of divorce had not been exercised by legislation applying throughout Canada although, for example, Acts were passed in 1930 relating to the Province of Ontario. It is accepted that insofar as property rights are varied on divorce, they fall within the federal sphere, but it has, for example, been judicially suggested ${ }^{1}$ that lump sums awarded as corollary relief on divorce must be restricted to the equivalent of maintenance payments and not encroach on redistribution of capital, which is within the provincial and not the federal sphere. The division of powers between provincial and federal authority creates many such fine distinctions.

\section{Separation of Property Rights Between Spouses}

To the inhabitants of the Northwest Territories of Canada, even in the late nineteenth century the question of property rights of married women was unlikely to bulk so large as in the more populous East, ${ }^{2}$ and far less than in the teeming cities of England, where the advent of machinery and the spread of literacy ${ }^{3}$ had for the first time made it possible for a woman, married or single, to earn something exceeding the bare cost of her subsistence. However, in 1890, an Ordinance of the Northwest Territories of Canada, effective in what was to become the Province of Alberta, amongst other areas, provided that "A married woman shall in respect of personal property be under no disabilities whatsoever heretofore existing by reason of her coverture or otherwise but shall in respect of the same have all the rights and be subject to all the liabilities of a feme sole."4 In 1922 the Province of Alberta enacted its first Married Women's Act, ${ }^{5}$ declaring succinctly in s. 2 that: "A married woman shall be capable of acquiring, holding and disposing of or otherwise dealing with all classes of real and personal property, and of contracting, suing and being sued in any form of action or prosecution as if she were an unmarried woman." Rather more elaborate provisions followed in its replacement, the Married Women's Act of 1936, which is in fact the current statute, only slightly

1. By Moir, Justice of Appeal of the Supreme Court of Alberta, in Krause v. Krause (1976) 23 R.F.L., 219, 227, cited with approval by Miller J. of the Trial Division of the Alberta Supreme Court, in Kronenberger v. Kronenberger [1977] 4 A.R. 546 at 557.

2 In Ontario, for example, the first Married Women's Property Act was passed on 25th March 1884, $\mathrm{Ch}$. 19, effective 1st July, 1884.

3. A. V. Dicey, Law and Opinion in England During the Nineteenth Century, Ch. 11, cites women authors and actresses as among the first women to earn money that began to matter, and finds in such earnings the mainspring for the reform of the law of married women's property.

4. An Ordinance respecting the Personal Property of Married Women, No. 20 of 1890, в. 2.

5. Alberta is the only Canadian province to choose and retain such a title to its Act. In all other provinces of Canada, as in England and elsewhere, the relevant Act is called the Married Women's Property Act. 
amended, and now under consideration for major amendment by the Matrimonial Property Bill, Bill No. 102, beofre the Alberta Legislature.

In 1926, on an appeal from Alberta, the Judicial Committee of the Privy Council, sitting in England, held ${ }^{6}$ that even a judicially-separated married woman was inescapably fixed with the domicile of her husband. Alberta lost no time in reversing by statute ${ }^{7}$ this decision, from which married women in England escaped only in $1973 .^{8}$

The result of the Married Women Acts in Alberta, and of the Married Women's Property Acts in England and the common law Canadian provinces, and elsewhere in the common law world from 1870 onwards, has been similar. In place of the unity achieved by submerging the wife's legal rights and vesting all legal rights in the husband alone, these Acts have (subject to the major unenforceable common-law duty of maintenance ${ }^{9}$ ) separated the property and other rights of husband and wife and treated them as if they were strangers. All that a husband owned on marriage and subsequently acquired was his and his alone. All that a wife owned on marriage and subsequently acquired was hers and hers alone: BUT-retaining the ineffective common law rule based on the principle of unity in the husband-a husband was obliged to support his wife at the standard he deemed appropriate, provided the wife committed no matrimonial offence.

\section{The Movement Away from Separate Property in Common Law Countries}

These efforts to apply to husband and wife the law as between strangers have also been found unsatisfactory over the years. They probably applied reasonably well to spouses each of whom had independent income from capital. Separation of property had two outstanding merits: (i) simplicity; who owned what was rarely in doubt; (ii) the practice of managing her own property, however small, is crucial to the social responsibility of the married woman. On the other hand, increasingly it has become clear that the result of separation of property is to discriminate first, against the married woman who stays at home to care for the home, husband and children in favour of the wife who seeks an independent income outside the home, and secondly, in favour of earning wives 10 who take care that it is the husband's money that is used to feed, clothe and warm the family, whilst their own is carefully shepherded into assets that will remain exclusively their own, or if bought partly with money from the husband, half theirs. However, most women who earn, especially those with young children, tend to use their earn-

6. Attorney General for Alberta v. Cook [1926] A.C. 444.

7. By the Domestic Relations Act 1927, c. 5, \&. 10 of which provided that a judicially-8eparated wife 'shall ... be reckoned as sui juris and as an independent person for all purposes, including the acquisition of a new domicile distinct from that of her husband.' The provision is now embodied in the Domestic Relations Act, R.S.A. 1970, c. 113, s. 11

8. By the Domicile and Matrimonial Proceedings Act, 1973, c. 45, s. 1(1) of which, at long last and after much effort over many years, included the provision: ". . . the domicile of a married woman as at any time after the coming into force of this section shall, instead of being the same as her husband's by virtue only of marriage, be ascertained by reference to the same factors as in the case of any other individual capable of having an independent domicile".

9. There are other areas, such as Social Security, in which the family is treated as a unit, and in which the husband may claim payments in respect of himself and his dependents. In England but not in Canada, husband and wife are still treated as a unit for purposes of direct taxation.

10. Such as the English Mrs. Rimmer, of Rimmer v. Rimmer [1953] 1 Q.B. 63. Whilst her husband was on war service she carefully used his allowance for her daily living, using her own earnings to repay the mortgage on the house, which greatly increased in value because of the war. This established her right as part provider of the purchase money to share in the value of the house when sold, although it stood in her husband's sole name. 
ings for food, clothes, travel and luxuries for the family as a whole and especially the children, so that no asset remains which the wife can claim as purchaser.

From at least the turn of the century, but increasingly since the war of 1939-1945, efforts have been made to mitigate the effects of separate property. These have taken the following forms:

(a) Starting with New Zealand in $1900^{11}$ the monstrous heresy that every duty of maintenance ceased at death has been exploded by the enactment of statutes ${ }^{12}$ imposing flexible restraints on testamentary freedom. Unlike the provisions for legitim, or for a forced share of the deceased's property for some or all of those dependent on him at his death, the general scheme of these statutes is that those dependent on the deceased may apply to the court if they think inadequate the provision made for them by the will of the person on whom they depended or the general law of intestacy. The court may (not must) make provision for them from the net estate left by the deceased. Alberta was the first province in Canada to adopt this system, by its Married Women's Relief Act of $1910.1^{13}$ The statutes then travelled eastwards across Canada, reaching Ontario in 1927 and Prince Edward Island in 1947. The current Alberta statute is the Family Relief Act, which provides for applications to the courts by the surviving spouse ${ }^{14}$ of the deceased or by minor children or incapacitated children.

(b) The Matrimonial Home. Unsuccessful attempts were made by the English courts in the 1950's to prevent a wife from being evicted from the matrimonial home by a husband or his creditors. So considerable a change could not be effected by judicial decision, but in the Matrimonial Homes Act $1967^{15}$ the British Parliament provided that the owner of the matrimonial home could no longer lock out or evict his or her spouse, and the non-owning spouse was enabled to register her or his occupation right against the title of the other, which served as notice to creditors. In the four western provinces of Canada protective provisions have been made under statutes known as Homestead Acts in British Columbia and Saskatchewan and Dower Acts in Manitoba and Alberta. This legislation has no resemblance to dower in English common law, but resembles the Homestead legislation of the southern and western states of the United States.

(c) Maintenance or support payments. From the latter part of the last century all common law countries have had provisions under which the spouse who is deserted or not supported by the other may obtain from the court an order that the other should pay a stated amount each week or month for the maintenance or support of the dependent spouse and children. Court orders still do not produce money, although until comparatively recently there was a general impression that they were

11. The New Zealand Family Protection Act, 1900 (64 Vict. 20).

12. Variously called Dependants' Relief or Testators' Family Maintenance Acts in Canada and Australia. In England the first statute was the Inheritance (Family Provision) Act 1938, now replaced by the Inheritance (Provision for Family and Dependants) Act, 1975.

13. Second Session Ch. 18. The long title is: An Act Respecting the Rights of Married Women in the Estates of their Deceased Husbands.

14. It will be noted that the rights of the surviving widow have now rightly been extended to whichever spouse survives the other and is in need. The acceptance of obligations is fundamental to the assertion of legal rights by women. The Province of Quebec still has neither legitim nor Family Relief.

15. The Act was introduced after the House of Lords had struck down the spurious "deserted wife's equity" by the decision in National Provincial Bank v. Ainsworth [1965] A.C. 1175. The statute improves on the caselaw in protecting either spouse in all circumstances except bankruptcy and not only the deserted wife, but unfortunately it gives no independent protection to minor children. 
effective. When after the war of 1939-45 the public purse in England took on the liability of ensuring minimum support for all citizens, the extent to which those liable were failing to ensure the maintenance of their dependants became alarmingly clear in the size of the welfare payments required. Enforcement provisions were strengthened, in particular by enabling the courts to retain part of the wages or earnings of the person liable by making orders on his employer. In England this was done first by the Maintenance Orders Act 1958, which gave place to the Attachment of Earnings Act 1971. Several provinces of Canada, including Alberta, are making or have made similar provisions. Under the Divorce Act 1968 the federal Canadian courts have power on divorce to order payment of lump sums and not only periodical payments. Such a power was introduced in England in the Matrimonial Causes Act, 1963, and Canadian provincial legislation is taking the same path.

(d) There was an old rule, dating back to the days when a married woman could not claim "separate" property unless she could show her husband's recognition of such "separation", that if a man bought and paid for property but had it conveyed or transferred to his wife, the law would presume that he intended to make a gift to her of the property, and he could not be heard to say that he intended her to hold it as trustee for him. This was called the "presumption of advancement", and in many common law countries, including Canada, it is now in decline. ${ }^{16}$

In view of the presumption, however, it is strange that by a disastrous series of decisions the courts in common law countries held that if a man gave his wife money for housekeeping and she contrived to save some of it, the savings and anything she might buy with them belonged exclusively to him. Since the money had been given for joint purposes in the first instance, it is incomprehensible that the courts consistently refused to hold that when saved or used to buy durable property it continued to belong to both. In England the matter was rectified by the Married Women's Property Act 1964, but in Canada the husband's exclusive right appears to remain.

If a woman paid in whole or in part for property which was conveyed to her husband, the law did not necessarily presume that she intended to make a gift of it to him. During and after the war of 1939-1945 it became increasingly common for women to earn money before and during their marriage and even after the birth of children. Increasing numbers of wives became continuously employed once their children attended school. The spread of divorce alerted more people to the plight of the woman who was divorced in middle age and had no marketable skills with which she could thereafter support herself, and possibly young children.

The husband almost invariably acquired other dependants to support. Women who earned became more skilled and circumspect in investing their savings. The war also resulted, directly or indirectly, in noticeable increases in the value of some types of property, particularly immoveables, land and houses. From the late 1940's the English courts received increasing numbers of claims, usually by wives but in some cases $^{17}$ from husbands, for a right to some proportion (usually half) of

16. See the English cases of Falconer v. Falconer [1970] 1 W.L.R. 1333 at 1335-6, Pettitt v. Pettitt [1970] A.C. 777 at 793, 811,874-5 and Gissing v. Gissing [1971] A.C. 886 at 907. The statements in Pettitt v. Pettitt as above were cited with approval in the majority judgment delivered by Dickson $\mathrm{J}$. in the Supreme Court of Canada in the recent case of Rathwell $v$. Rathwell, 19th January, 1978. The presumption was abolished in Ontario by the Family Law Reform Act 1975, 8. 1(3)(d).

17. For example Pettitt v. Pettitt [1970] A.C. 777. 
some specific asset, to which the other spouse appeared to be the sole legal owner. This was usually but not invariably the matrimonial home. The basis of the claim might be that it had been so agreed, or that she had contributed to the purchase or the increased value of the asset either by:

(a) providing part of the first (down) payment with which ownership was secured, or

(b) providing part of subsequent payments by which ownership was retained or increased, or

(c) contributing by her labour, thus freeing the husband for more lucrative work which enabled him to buy the property.

An allegation of an agreement, express or implied, that the property should belong to both in equal shares was frequently attached to alternative claims. Where the agreement had been implemented by vesting the property in joint names the courts would of course give effect to it and hold the wife entitled to the share of the property indicated. In many cases the courts would attempt to find an implied agreement for some share for the wife, but the fact was that in most cases the property had been acquired on the understanding by both spouses that they would remain married. Neither, and more particularly the woman, had seriously considered, far less made any agreement about, what the position would be in the event of divorce. ${ }^{18}$ With the spread of divorce it is becoming increasingly obvious that women must consider before they marry what their financial circumstances will be in the event of divorce.

(a) From the 1950's the courts both in England and in Canada increasingly held that in the rare cases where the woman had been circumspect enough to make and retain records clearly showing that her own separate money had been commingled with her husband's money or used separately to buy property, she was entitled to share in the value of that property to the extent of her contribution. Where the contribution was undoubted but its amount was very difficult to assess (as was more probable in claims for continuing payments under (b)), the courts began to hold the two spouses equally entitled, ${ }^{19}$ and undoubtedly the decisions that the wife was entitled to an equal share after what might be a minimal monetary contribution were pressed too far. ${ }^{20}$ On the other hand, the majority decision of the Supreme Court of Canada pointed out in Rathwell v. Rathwell recently that "the manner in which title is recorded may simply reflect the conveyancing in vogue at the time as, for example, the practice in Western Canada of placing title to farmland in the name of the husband." Similarly in England, until recently it was unusual for the home to be conveyed to or registered in the joint names of husband and wife. In the $1950^{\prime} \mathrm{s}$ fashion began to change, and increasingly parents of the bride would insist that before their daughter married she be

18. In the recent case of Rathwell v. Rathwell, on which the Supreme Court, the highest court in Canada, delivered judgment in January, 1978, the court referred to the continuing struggle between the "justice and equity" school and the "intent" school. The charge raised against the first was said to be that of dispensing "palm-tree" justice; against the latter school, that of a meaningless ritual in searching for a phantom intent. In the Judicial Committee of the House of Lords, the highest court of appeal in England, Lord Hodson said in Pettitt v. Pettitt [1970] A.C. 777, 810 at F, that "the concept of a normal married couple 8pending the long winter evenings hammering out agreements about their possessions appears grotesque". Even if agreements are reached, they are not always recorded and sometimes for technical reasons written evidence or a sealed deed is essential.

19. As in Rimmer v. Rimmer [1953] 1 Q.B. 63, where strict accounting would have given the wife two-thirds of the value, but only because she had lived on her husband's money and used her own to pay for the house, which had increased in value by about five times.

20. Lord Reid said in Gissing v. Gissing [1971] A.C. 886 at 897 "the high-sounding brocard equality is equity has been misused", and the Supreme Court of Canada recently repeated the comment in Rathwell v. Rathwell. 
unequivocally recognized as joint owner of her new home, with rights of property in it equal to those of the husband.

One difficulty in claims under (b) was that contributions might have been made without the knowledge of the other spouse, and for example in Pettitt v. Pettitt ${ }^{21}$ the House of Lords held that a husband could not claim that he was entitled to a share in the value of his wife's house because he had spent time and money improving it. In England, but not so far in Canada, it has now been provided by statute ${ }^{22}$ that if one spouse contributes substantially, in money or money's worth, to the improvement of property belonging to the other spouse, subject to any agreement to the contrary express or implied, the spouse who has so improved the property of the other is entitled to a beneficial interest in the whole property to the extent agreed, or failing agreement, as may seem in all the circimstances just to any court before which the question arises.

As regards (c) in Canada the situation was stated in the lower court in Murdoch v. Murdoch to be that "no case has yet held that in the absence of financial contribution the mere fact of marriage and cohabitation and the fact that the property is the matrimonial home gives the wife any interest".

The present situation in Alberta is demonstrated by the two decisions of the Supreme Court of Canada in Murdoch v. Murdoch ${ }^{23}$ and Rathwell v. Rathwell, the facts of which were not dissimilar. In Murdoch the parties married in 1943 and separated in 1968, so that marriage lasted 25 years. At first they hired themselves out as ranch hands, the wife working alongside the husband, and received their board and lodging and $\$ 100 \mathrm{a}$ month, all of which the husband took. Four years later he used some of these joint earnings to put up half the cost of land, the other half being provided by the wife's father. The wife ran this land alone as a ranch receiving guests for the five months of the year when the husband was away in employment elsewhere, but when it was sold after four years the husband alone collected half the sale price. Later the husband received from either the wife or her mother further money which he loaned out in return for grazing rights. Again the husband alone collected the loan when it was repaid. More land was bought in his sole name. In 1964 the wife asserted her rights under the Dower Act to prevent the husband from selling the land on which the matrimonial home stood, and the married relations deteriorated. When, after a judicial separation, the wife claimed a half share as an equal partner in all the land and other assets owned by the husband, her claim was dismissed and by a majority of four judges to one she was held entitled to nothing other than the $\$ 200$ a month that her husband had been ordered to pay for her maintenance. On a subsequent divorce, however, she received an additional substantial lump sum payment.

As a guest in Alberta and in Canada I venture to say that in my opinion the decision is clearly not only unjust but wrong in law. The husband had pocketed the wife's earnings as well as his own and it was from the savings from both that he was able to start buying land. The wife ran the land for nearly half the year when he was earning money elsewhere, and it was her parents who supplied money (free of interest)

21. [1970] A.C. 777.

22. Matrimonial Proceedings and Property Act 1970, s. 37, not consolidated in the Matrimonial Causes Act 1973, but still in operation. The wording leaves considerable scope for judicial discretion.

23. [1975] 1 S.C.R. 423. 
with which the husband was able to buy more land, which he sold at a profit, to all of which he was held solely entitled.

Of particular interest is the fact that the sole judge who dissented would have held that the wife was entitled to a share in the land on the basis of both her financial contributions and her physical labour (which he described as extraordinary). Two months later this judge was appointed Chief Justice of Canada. In Chief Justice Bora Laskin Canada clearly now has a Chief Justice who is on record as standing, alone when necessary, for justice in married relations and property rights for Canadian women.

Rathwell v. Rathwell came before the Supreme Court of Canada from the province of Saskatchewan in May, 1977 and judgment was delivered in January, 1978. By a majority of five to one the wife was held entitled to a half interest in all the farmland standing in the sole name of the husband. Here the marriage took place in 1944 and lasted for 23 years, until 1967. The major differences that enabled the court to distinguish the facts from those in Murdoch were that after the war of 1939-45 the couple opened a joint account in which both deposited their wartime savings of approximately equal amounts. This joint account was used to buy land and more land. This was also farmland. The wife not only did the chores, she looked after the garden; canned the produce; milked cows and sold cream; baled hay; provided meals and transport for hired help; kept the books and records. Often she drove a school bus in fulfilment of her husband's obligation while he worked in the fields. She also raised and educated four children. Her case as beneficiary under a constructive trust may also have been better argued than that of Mrs. Murdoch. She will spend her middle and advanced years independent of maintenance payments that might not reach her from an estranged former husband.

\section{CURRENT LEGISLATION: THE FIELD OF CHOICE}

Separation of property has been tried and found wanting; its simplicity proved too stern and rugged and will never return. Women everywhere have sought to escape regimes of total community of property, in which all management and control normally vest in the husband; the married woman may even have no independent contractual capacity. Systems of community of gains found in eight states of the United States have needed amendment, ${ }^{24}$ but may still cause hardship. ${ }^{25}$ Many of the disadvantages are eliminated in the system elaborated in Federal (West) Germany under the Equal Rights Law of July, 1957 (Gleichberechtigungsgesetz), ${ }^{26}$ under which each spouse manages and controls his or her property as if it were separate, but on dissolution of the marriage an accounting procedure takes place as a result of which the one who has gained more pays the other a sum calculated to equalize their gains during the marriage. This has come to be known as a system of 'deferred community', although there is at no time any community. 'Deferred sharing' has undertones of inequality during marriage.

24. Texas has progressively reformed its system since 1968; California boggled at the task when it enacted its Family Law Act in 1969, but in $1973-74$ by $\mathrm{Ch}$. 1206 it provided for joint management and control of community personalty.

25. See, for example, Brigitte Bodenheimer, The Community Without Community Property. California Western L. Rev. (1972) 381 .

26. The Danish system is similar, but includes the property of each owned before the marriage. See I. M. Pedersen, Matrimonial Property Law in Denmark, 28 M.L.R. (1965) 137. A controversial exclusion is that of property received by gift, bequest or devise, see B.G.B. ss. 1363 et seq. as amended by the First Marriage and Family Law Reform Act (Erstes Gesetz zur Reform des Ehe- und Familienrechts) of 14th June, 1976. 
A Bill that would have provided for the courts to start from the presumption that both spouses were equally entitled to all property owned by either was in 1969 given a Second Reading in the British House of Commons, ${ }^{27}$ but the solution finally adopted ${ }^{28}$ in England was for the courts to be given a list of 13 guidelines as "matters to be taken into consideration" in considering how to re-allocate property between the spouses on divorce. The failure to lay down definite rules for division, or a presumption of equal division as a starting point, enabled the Court of Appeal in Wachtel v. Wachtel ${ }^{29}$ to reverse a decision at first instance that the value of the matrimonial home $e^{30}$ be divided equally between the spouses, and replace it by a decision that the wife was entitled to onethird and the husband to two-thirds of the property. The English Court of Appeal has therefore now revived the old "onethird rule" which had been thought discredited. Although the court insisted that it was "not a rule, but a starting-point", it was also the finishing point in that and subsequent cases. This old rule, inherited from the Ecclesiastical courts, amounts to a declaration that a woman is presumed entitled to half as much as a man, and it is impossible to ignore its relationship, probably as direct ancestor, to the fact that in today's world women's earnings in general are about half the level of men's earnings.

Similarly in New Zealand, the courts were given discretion to decide on the allocation of property between husband and wife "having regard to the respective contributions of husband and wife to the property in dispute (whether in the form of money payments, services, prudent management or otherwise howsoever)". 31 The result was a case ${ }^{32}$ in which the parties had been married for thirty years and had five children before the wife applied to the courts for financial provision in 1970 , following separation in 1969. Marital disputes had arisen at least since 1958. The husband was a farmer whose land and its value greatly increased over the period. After the separation in 1969 he sold four-fifths of their land, including that on which the former matrimonial home stood. The remaining land was worth $\$ 60,000$ and the husband's total assets $\$ 118,000$. The wife had no home, no savings and no assets, and was compelled to live with one or other of the children. An award of one-fourth of the remaining land and $\$ 4,000$ for the wife made at first instance was reduced in the New Zealand Court of Appeal to a total of $\$ 5,000$. In a further appeal to the Judicial Committee of the Privy Council sitting in England (rare today for self-governing members of the Commonwealth) the original order was restored, but few would call it generous to a wife of thirty years.

In Alberta the Institute of Law Research and Reform produced in August, 1975 its Report No. 18 on Matrimonial Property. The majority proposal in that Report favoured a regime of equal division of gains made by the couple during marriage other than by gift or inheritance, similar to

27. By 86 votes to 32 . Such a vote expresses general approval and allows the Bill to proceed to the Committee stage As this was a Private Member's Bill, introduced by Mr. Edward Bishop, M.P., it was dependent on the Government for time in committee and was never enacted. The Bill is annexed as Appendix II to the Law Government for time in committee and was never enacted. The Bill is annexed as Appendix II to the Law
Commission Published Working Paper No. 42 Family Property Law, of 26 October, 1961. I do not disclaim responsibility for its drafting.

28. By the Matrimonial Proceedings and Property Act 1970, 8. 5, now the Matrimonial Causes Act $1973,8.25$. 29. [1973] Fam. 72

30. In that case, as in many others, it was the only asset of considerable value.

31. New Zealand Matrimonial Property Act 1963, s. 6. The section was strengthened in 1968, too late for Mrs. Haldane.

32 Haldane v. Haldane [1977] A.C. 673 P.C. 
the deferred sharing regime of Federal (West) Germany. The courts would have had discretion to deviate from equality for good cause. Bill No. 102, however, now before the Alberta Legislative Assembly, ${ }^{33}$ has adopted the minority proposal put forward in the Institute's Report, and would provide for judicial discretion, having regard to a number of 'guidelines' not unlike those in the English Act. ${ }^{34}$ In the light of history, and of recent experience in England and New Zealand, my personal view (here I do not and cannot speak for others) is that women should not hand over to an overwhelmingly male judiciary crucial questions about who provides the next meal and how.

Recent proposals for legislation in other provinces of Canada have provided for equal division on breakdown or termination of marriage of some or all of the property owned by either spouse. In Manitoba the Marital Property Bill ${ }^{35}$ would have provided for a standard marital regime under which (1) cohabiting spouses would have been deemed joint owners or tenants of their marital homes and (2) there would have been accounting and equal sharing of all commercial assets owned by either spouse, less debts and liabilities. There were provisions for contracting out of the regime. In British Columbia the Family Relations Amendment Bill ${ }^{36}$ defined 'family assets' in some detail and declared that each spouse was entitled to an equal share on breakdown of marriage, but with provision for deviation from equal division in a number of specified circumstances where it would operate unfairly. In Ontario, the Family Law Reform Act is on lines similar to the proposals introduced in British Columbia. It also defines 'family assets' in some detail, provides for their equal division, but allows the court in specified circumstances to deviate from equal shares where such a division would be inequitable. This Act is now in operation. ${ }^{37}$

My personal view (and here I cannot and do not speak for others) is that the following are the main principles that should be laid down in current legislation:

(a) There should be a definite rule or presumption that on dissolution or breakdown of a marriage husband and wife are equally entitled to the property owned by either or both, and acquired during the marriage. Enforcement measures must be swift and strong. There must be no delay or evasion in the transfer of property or payment of money to the other spouse.

(b) Some judicial discretion to deviate from equal division in exceptional cases is desirable, but should require explicit justification in each case. Mere acceptance of an existing rule, whether of the medieval church or otherwise, would not suffice.

(c) The number and extent of exceptions from equal division are

33. Bills Nos. 102 and 103: The Matrimonial Property Act and the Matrimonial Home Possession Act were both laid before the Legislative Assembly of Alberta in the fall of 1977 and allowed to die on the order paper to allow opportunity for comment. The Government of Alberta intends to revive them in spring, 1978.

34. In a recent survey conducted by the Centre for Socio-Legal Studies at Wolfson College, Oxford, England, one of the Registrars exercising jurisdiction in England in respect of matrimonial property said, in reply to questions about the matters to be taken into consideration in the Matrimonial Cases Act 1973, 8. 25 "it is rather like owinging a golf club-there are so many considerations to consider simultaneously." Report para. 3.30, at 45 .

35. The Manitoba Bill has been withdrawn.

36. This British Columbia Bill has also been withdrawn, but only so that its provisions, slightly amended, may be embodied in a consolidation of all existing law regarding family relations. It is thought that the revised provisions may call for equal division (subject to deviation) of all assets with some exceptions, rather than attempt to define 'family assets'.

37. From March 31, 1978. 
matters for negotiation, probably in the light of local conditions and the law of succession to property. I see no justification for a blanket exception for all property received by gift, bequest or devise. In any event difficult marginal distinctions must be made. This is perhaps an area for the exercise of judicial discretion, but with overall legislative control favouring equal entitlement.

(d) Spouses should be free, both before and during the marriage, to contract out of the regime and make other arrangements, but there should remain in the courts a discretion to decide whether (i) the agreement made was reasonable and (ii) the consent of both parties was a true consent freely given in full knowledge of all the relevant circumstances.

(e) Subject to any arrangements made by the parties-which could be informal and freely variable-separate administration by both spouses during the marriage of property held and income received, from whatever source, seems both socially desirable, practical and simple.

In conclusion I take this opportunity of expressing my thanks to the Director and Associate Director of the Institute of Law Research and Reform, Messrs. W. H. Hurlburt and Gordon Bale, for their help in preparing this paper. They have been generous with their time and unstinting in their efforts to help one new to the Western Canadian jurisdictions. All remaining faults and all views expressed are, of course, entirely my own. 